Doroshenko, E., Sushko, R., Shamardin, V., Prykhodko, V., Shapovalova, I., Yelisieieva, D., Demidova, O., \& Yakovenko, A. (2020). Analysis of the Competitive Activity Structure of Skilled Female Basketball Players. Teoriâ ta Metodika Fizičnogo Vihovannâ, 20(4), 219-227. https://doi.org/10.17309/tmfv.2020.4.04

ISSN 1993-7989 (print). ISSN 1993-7997 (online)

\title{
ANALYSIS OF THE COMPETITIVE ACTIVITY STRUCTURE OF SKILLED FEMALE BASKETBALL PLAYERS
}

\author{
Eduard Doroshenko ${ }^{1 \mathrm{ABCD}}$, Ruslana Sushko ${ }^{2 \mathrm{ABCD}}$, Valerij Shamardin ${ }^{3 \mathrm{CDE}}$, \\ Volodymyr Prykhodko $^{4 \mathrm{CDE}}$, Iryna Shapovalova ${ }^{1 \mathrm{DE}}$, Daria Yelisieieva $^{4 \mathrm{DE}}$, \\ Oksana Demidova ${ }^{4 \mathrm{DE}}$, Artem Yakovenko ${ }^{4 \mathrm{DE}}$
}

${ }^{1}$ Zaporizhzhia State Medical University

${ }^{2}$ Borys Grinchenko Kyiv University

${ }^{3}$ Ukrainian Football Association Licensing Center

${ }^{4}$ Prydniprovska State Academy of Physical Culture and Sports

Authors' Contribution: A - Study design; B - Data collection; C - Statistical analysis; D - Manuscript Preparation; E - Funds Collection

Corresponding Author: Ruslana Sushko, E-mail: r.sushko@kubg.edu.ua

Accepted for Publication: December 20, 2020

Published: December 25, 2020

DOI: 10.17309/tmfv.2020.4.04

\begin{abstract}
The study purpose was to examine, analyze, and generalize the competitive activity structure based on the hierarchy of technical and tactical indicators of skilled female basketball players in won and lost games using principal component analysis.

Materials and methods. The study participants were 96 professional female basketball players, members of national teams of Spain, France, Belgium, Greece, Turkey, Latvia, Italy, and Slovakia, which took the 1st-8th places in the final tournament of the European Basketball Championship 2017. The study analyzed 16 main technical and tactical indicators of skilled female basketball players in 52 official games to examine and interpret the obtained results using principal component analysis. The total number of observations is 52 .

Results. The experimental indicators obtained during the study made it possible to examine and analyze the grouping of elements of the competitive activity structure of skilled female basketball players, to interpret the obtained results in order to define informative criteria for optimizing training and improving the competitive activity effectiveness. The study revealed considerable differences in the competitive activity structure in won and lost games: in accordance with the most significant indicators of factor loadings, the percentage of a sample of elements that correlate with one another is: for won games $-67.40 \%$, for lost games $-69.52 \%$.

Conclusions. Principal component analysis is quite effective and informative for studying the competitive activity structure of skilled female basketball players. It was demonstrated that the greatest difficulties in studying the competitive activity structure in basketball using principal component analysis are the selection of indicators that do not duplicate one another and are not calculated, expert interpretation of the obtained results, and algorithmization of special analysis of technical and tactical indicators.

Keywords: basketball, structure, technical and tactical activity, principal component analysis.
\end{abstract}

\section{Introduction}

Modern basketball is characterized by strong competition at the level of club and national teams (Okazaki, Rodacki, \& Satern, 2015; Sushko, Vysochina, Vorobiova, Doroshenko, Pastuhova, \& Vysochin, 2019). This determines the popularity of basketball: increased attention of millions of

(C) Doroshenko, E., Sushko, R., Shamardin, V., Prykhodko, V., Shapovalova, I., Yelisieieva, D., Demidova, O.,

Yakovenko, A., 2020. fans and viewers, managers of business structures and investment companies, researchers and practitioners (Calvo, García, \& Navandar, 2017; Kozina, Bazylyuk, \& Boyko, 2017). The high level of technical and tactical skills and training system of top athletes suggests the need to search for new, nontraditional approaches to creating the most effective methods for increasing the competitive activity efficiency in sports games (Tao Zhang, Gongzhu Hu, \& Qi Liao, 2013; Križan \& Mikulič, 2018). One of the most relevant issues in the modern system of training skilled athletes in sports games is the 
use of methods of multivariate mathematical analysis of the competitive activity indicators (Kawabata \& Mallett, 2012) and their further interpretation (Makuts \& Vysochina, 2015). This makes it possible to integrate the multivariate methods of mathematical and statistical analysis into the theory of athletic training in basketball in order to improve the system of long-term training and competitive activity of skilled athletes (Wei Yin, 2014). These methodological approaches are of great practical importance (Vlachopoulos, Karageorghis, \& Terry, 2000), and the problematic issues are promising areas for effective implementation in the system of athletic training (Li, Wang, Chen, \& Dai, 2015) and improvement of the competitive activity efficiency (Shepelenko, Kozina, Cieślicka, Prusik, Muszkieta, Sobko, Ryepko, Bazilyuk, Polishchuk, Osiptsov, \& Kostiukevych, 2017).

Among promising experimental studies in this research area are the papers by Cieślicka, Sobko, Ulaeva, Ishenko, Shepelenko, Tamozhanska, \& Bugayets, 2019; Gryko, Mikołajec, Maszczyk, Cao, \& Adamczyk, 2017, which, based on the material of team games and using the multivariate methods of mathematical analysis, examined the physical fitness structure of athletes with different positions and determined the factor models of technical and tactical actions in the competitive activity. At the present stage of sports science development, one of the first experimental studies of the competitive activity structure of skilled female basketball players using factor analysis methods is the research paper by Kyrychenko and Doroshenko (2006), which is based on the material of technical and tactical indicators of the competitive activity in the Euroleague and EuropaCup 2003-2005 official games. A distinctive feature of the study is a modified use of principal component analysis with Kaiser normalization, varimax orthogonal rotation of the primary $\mathrm{R}$ matrix and subsequent interpretation of the obtained data to develop an algorithm for special analysis of indicators of the competitive activity in basketball.

This research area was further developed in the papers by Calvo, García, and Navandar (2017) (study of technical and tactical indicators in the competitive activity of professional athletes in the Spanish Basketball League); Gryko, Mikołajec, Maszczyk, Cao, and Adamczyk (2017) (analysis of technical and tactical indicators in the competitive activity of basketball players in the final tournament of the European Championship 2015); Teck, Wang, and Mallett (2012) (technical and tactical characteristics in the competitive activity of elite women's basketball teams while preparing for youth Olympic tournaments).

The problems with using the methods of multivariate mathematical analysis when grouping technical and tactical indicators in the competitive activity of basketball players, taking into account their differentiation into individual, group, and team values, are described in the studies by Kozina, Jagiello, and Jagiello (2015); Kozina, Bazylyuk, and Boyko (2017), as well as when analyzing the hidden components of the competitive activity structure (Sporiš, Šango, Vučetić, \& Mašina, 2006). The authors point out that the most important problem is a high complexity of qualitative interpretation of collected data, which is based on practical experience, theoretical and methodological knowledge of researchers, the use of modern computer technology in the process of multivariate mathematical analysis.

Modern methodological approaches to analyzing factor variables that determine the parameters of teamwork of skilled basketball players in the conditions of growing competition, and to forming the groups of factors are presented in the study by Bazanov, Võhandu, \& Haljand, 2006. This makes it possible to develop a set of necessary prerequisites for improving the indicators of integrated team skills based on the teamwork of individual members of the team: "point guard - shooting guard", "small forward - power forward center", and others.

A similar approach was implemented in the study by Sampaio, Janeira, Ibáñez, \& Lorenzo (2006), which determines the individual characteristics of the integrated skills of athletes with different positions (point guard, shooting guard, small forward, power forward, center), using the methods of mathematical modeling and multivariate mathematical analysis. The study showed the possibilities of theoretical modeling in multivariate mathematical analysis of technical and tactical indicators in the competitive activity in basketball based on the formation of models of a player with a specific role according to the principle of "leading qualities". The use of this principle in the training process is of great practical importance, since it enables differentiation of the focus of training effects in order to select the most effective exercises.

The formation of an algorithm for selecting test tasks that meet the criteria of objectivity, reliability, validity, and informativity (Kozina, Repko, Ionova, Boychuk, \& Korobeinikov, 2016) and make it possible to determine the level of development of various aspects of basketball players' fitness at different stages of long-term improvement, is one of the most relevant tasks in applying the methods of multivariate mathematical analysis for studying the competitive activity in basketball (Koryahin, Dutchak, Iedynak, Blavt, Galamandjuk, \& Cherepovska, 2018).

The use of the methods of multivariate mathematical analysis of technical and tactical indicators in the competitive activity of skilled basketball players is also highlighted in the study by Scanlan, Dascombe, and Reaburn (2011), which, on the basis of comparative analysis of elementary technical and tactical actions of basketball players of the Australian National Basketball League, shows the need to study the hidden structure of standard indicators of game efficiency in basketball, which significantly supplements the modern approaches to special analysis of indicators of the competitive activity and the formation of its algorithm. The discriminant analysis of game indicators of basketball players with different positions is shown as an adequate, reliable, and informative method for studying technical and tactical indicators and is a necessary prerequisite for developing an algorithm for special analysis of the competitive activity in basketball (Villa \& Lozano, 2018).

Consequently, the methods of multivariate mathematical analysis are adequate both in the study of theoretical (Ferreira, Volossovitch, \& Sampaio, 2014), and applied (Pluta \& Andrzejewski, 2018) problems of analyzing the competitive activity structure of skilled athletes in basketball. The present study has examined the indicators of the competitive activity structure of skilled female basketball players in the official games of the European Basketball Championship 2017, using principal component analysis.

The study of the peculiarities of technical and tactical actions in the competitive activity of skilled female basketball players and the interpretation of the obtained results using principal component analysis will create the prerequisites for 
developing an algorithm for special analysis of indicators of the competitive activity in basketball.

Hypothesis. The grouping of elements of the competitive activity structure of skilled female basketball players using principal component analysis has significant differences in technical and tactical indicators in won and lost games. Therefore, it needs to be studied in order to increase the effectiveness of the training and competitive activity.

The study purpose was to examine, analyze, and generalize the competitive activity structure based on the hierarchy of technical and tactical indicators of skilled female basketball players in won and lost games using principal component analysis.

\section{Materials and methods}

\section{Study participants}

The study object was technical and tactical indicators in the competitive activity of 96 skilled female basketball players, members of national teams of Spain, France, Belgium, Greece, Turkey, Latvia, Italy, and Slovakia, which took the 1st-8th places in the final tournament of the European Basketball Championship 2017. Principal component analysis was used to study the competitive activity structure indicators to group the leading factors, determine their hierarchy, and interpret the obtained results regarding the differences in won and lost games. During experimental research, we processed 8,784 technical and tactical indicators in the competitive activity of skilled female basketball players in 52 games of the final tournament of the European Basketball Championship 2017: 5,392 indicators of the competitive activity of skilled female basketball players in 32 won games and 3,392 indicators in 20 lost games.

\section{Study organization}

On June 16-25, 2017, the Czech Republic hosted the final tournament of the European Women's Basketball Championship. Its participants were 16 strongest national teams. The results of the top 8 teams (total number of games, number of wins and losses) are given in Table 1.

\section{Statistical analysis}

To study the competitive activity structure of skilled female basketball players based on the materials of the final tournament of the European Basketball Championship 2017, principal component analysis was used as a form of factor analysis (Jiang, 2014; Wei, 2014). The study performed an analysis of the grouping of elements of the competitive activity structure by the individual technical and tactical indicators of skilled female basketball players. The indicators in won and lost games were differentiated and generalized. To process the obtained results, specialists of the Department of Physical Rehabilitation, Sports Medicine, Physical Education and Health of Zaporizhzhia State Medical University used the SPSS-12 computer program.

\section{Results}

Tables 2 and 3 present the factor coefficients that make it possible to determine the competitive activity structure of
Table 1. Final results with the ratio of wins and losses of skilled female basketball players in the games of the final tournament of the European Basketball Championship $2017, \mathrm{n}=52$

\begin{tabular}{clcccc}
\hline Place & Team & $\begin{array}{c}\text { Number of } \\
\text { games }\end{array}$ & Won & Lost & Ratio \\
\hline 1 & Spain & 6 & 5 & 1 & 5 \\
2 & France & 6 & 5 & 1 & 5 \\
3 & Belgium & 6 & 5 & 1 & 5 \\
4 & Greece & 7 & 3 & 4 & 0.75 \\
5 & Turkey & 6 & 5 & 1 & 5 \\
6 & Latvia & 7 & 3 & 4 & 0.75 \\
7 & Italy & 7 & 4 & 3 & 1.33 \\
8 & Slovakia & 7 & 2 & 5 & 0.4 \\
\hline Total & & 52 & 32 & 20 & 1.6 \\
\hline
\end{tabular}

skilled female basketball players, that is, are its elements, with differentiation into won and lost games.

To determine the specifics of the competitive activity structure of skilled female basketball players in won and lost games using principal component analysis, the corresponding technical and tactical indicators of the athletes were studied (Table 2, won games - 32; Table 3, lost games - 20).

In the case of our study, for the grouping of elements of the general competitive activity structure of skilled female basketball players, in accordance with the most significant indicators of factor loadings, the percentage of a sample of elements that significantly interrelate (correlate) with one another is: for won games $-67.40 \%$ (Table 2), for lost games $69.52 \%$ (Table 3 ). The obtained data point to a fairly high degree of reliability of the results.

The analysis of the distribution of technical and tactical indicators of skilled female basketball players in the hierarchical competitive activity structure in won and lost games reveals the existence of significant differences.

In the won games, the first factor "Ball control" includes the following technical and tactical indicators of the competitive activity: offensive rebounds, defensive rebounds, total rebounds, and blocks. Taking into account the specifics of the competitive activity in basketball, we state that these technical and tactical indicators reflect a great importance of ball control after attacking the opponent's basket: offensive rebounds and, partially, total rebounds. The quantitative indicators of defensive rebounds, blocks and, partially, total rebounds indicate a great importance of ball control after the opposing team's attacking technical and tactical actions. In addition, ball control after rebounds and, sometimes, after blocks enables the team to effectively use offensive technical and tactical actions, taking into account the tactical game plan and current game situation. In this case, the attacking team players may vary technical and tactical actions, using fast or positional tactical variants of attack, which significantly increases the competitive activity efficiency.

In the lost games, the first factor "Points scored in longdistance attack" includes the quantitative and qualitative indicators of 3-point shots, points scored, turnovers, and playing time. The expert interpretation of the obtained results shows that in the structure of basketball competitive activity in the lost games the indicators of shooting skills are of great 
Table 2. The competitive activity structure of skilled female basketball players in won games, $\mathrm{n}=32$

\begin{tabular}{|c|c|c|c|c|}
\hline \multirow[t]{2}{*}{ Competitive activity indicators } & \multicolumn{4}{|c|}{ Values of factor coefficients } \\
\hline & Factor 1 & Factor 2 & Factor 3 & Factor 4 \\
\hline Time, min. & 0.446 & 0.594 & 0.355 & 0.331 \\
\hline 2-point shots, $\mathrm{n}$ & 0.403 & 0.066 & 0.623 & 0.406 \\
\hline 2 -point shots, $\%$ & 0.454 & 0.086 & 0.609 & 0.397 \\
\hline 3-point shots, $n$ & 0.013 & 0.865 & 0.144 & -0.060 \\
\hline 3-point shots, $\%$ & 0.059 & 0.892 & 0.186 & 0.020 \\
\hline free throws, $\mathrm{n}$ & 0.081 & 0.168 & 0.913 & -0.019 \\
\hline free throws, $\%$ & 0.165 & 0.137 & 0.906 & -0.003 \\
\hline offensive rebound, $\mathrm{n}$ & 0.717 & -0.221 & 0.108 & 0.100 \\
\hline defensive rebound, $\mathrm{n}$ & 0.769 & 0.268 & 0.217 & 0.046 \\
\hline rebounds, $\mathrm{n}$ & 0.915 & 0.131 & 0.203 & 0.045 \\
\hline efficient assists, $\mathrm{n}$ & 0.011 & 0.583 & 0.194 & 0.304 \\
\hline fouls, $\mathrm{n}$ & 0.130 & -0.045 & -0.087 & 0.681 \\
\hline turnovers, $\mathrm{n}$ & 0.008 & 0.173 & 0.302 & 0.651 \\
\hline steals, n & 0.111 & 0.403 & 0.077 & 0.276 \\
\hline blocks, n & 0.462 & -0.217 & 0.264 & -0.088 \\
\hline points, $n$ & 0.256 & 0.537 & 0.716 & 0.186 \\
\hline total variance & 2.861 & 2.968 & 3.425 & 1.560 \\
\hline variance, \% & 17.8 & 18.5 & 21.4 & 9.70 \\
\hline
\end{tabular}

Table 3. The competitive activity structure of skilled female basketball players in lost games, $\mathrm{n}=20$

\begin{tabular}{|c|c|c|c|c|}
\hline \multirow[t]{2}{*}{ Competitive activity indicators } & \multicolumn{4}{|c|}{ Values of factor coefficients } \\
\hline & Factor 1 & Factor 2 & Factor 3 & Factor 4 \\
\hline Time, min. & 0.563 & 0.425 & 0.461 & 0.311 \\
\hline 2-point shots, $n$ & 0.490 & 0.401 & 0.013 & 0.547 \\
\hline 2 -point shots, $\%$ & 0.490 & 0.457 & 0.038 & 0.499 \\
\hline 3-point shots, $n$ & 0.870 & -0.113 & 0.060 & 0.078 \\
\hline 3 -point shots, $\%$ & 0.836 & -0.098 & 0.194 & 0.197 \\
\hline free throws, $\mathrm{n}$ & 0.132 & 0.133 & 0.088 & 0.926 \\
\hline free throws, $\%$ & 0.152 & 0.165 & 0.071 & 0.925 \\
\hline offensive rebound, $\mathrm{n}$ & -0.134 & 0.715 & -0.112 & 0.158 \\
\hline defensive rebound, $\mathrm{n}$ & 0.056 & 0.692 & 0.320 & 0.330 \\
\hline rebounds, $\mathrm{n}$ & -0.008 & 0.838 & 0.212 & 0.327 \\
\hline efficient assists, $\mathrm{n}$ & 0.386 & 0.028 & 0.705 & 0.094 \\
\hline fouls, $\mathrm{n}$ & 0.167 & 0.301 & 0.275 & 0.001 \\
\hline turnovers, $\mathrm{n}$ & 0.481 & 0.262 & 0.408 & 0.021 \\
\hline steals, $\mathrm{n}$ & 0.045 & 0.075 & 0.761 & 0.108 \\
\hline blocks, $\mathrm{n}$ & 0.130 & 0.654 & -0.264 & -0.026 \\
\hline points, $\mathrm{n}$ & 0.720 & 0.220 & 0.064 & 0.633 \\
\hline total variance & 3.268 & 2.958 & 1.824 & 3.069 \\
\hline variance, $\%$ & 20.40 & 18.40 & 11.40 & 19.20 \\
\hline
\end{tabular}

importance: quantitative and qualitative indicators of 3-point shots, points scored. The emphasis on using 3-point shots is usually conditioned by high-level defensive actions of the winning team. In these conditions, the losing team is forced to change the emphasis in offensive actions to throwing the ball into the basket from long distances. The indicators of turnovers, by their characteristics, are opposite to rebounds. If in the won games the quantitative indicators of rebounds belong to the first factor, which points to the predominant indicators of ball control, then in the lost games, the first factor includes the indicators of turnovers, which determine the reduced indicators of ball control in the competitive activity.
The indicator of points scored in the lost games belongs to the first factor, obviously due to a greater complexity and reduced efficiency of offensive technical and tactical actions. The indicator of playing time also belongs to the first factor, which indicates the existence of difficulties associated with a shortage of skilled athletes who can substitute players and increase the effectiveness of the losing team's technical and tactical actions. In the competitive activity structure of skilled female basketball players, the first factor is $17.8 \%$ in the won games, $20.4 \%$ - in the lost games.

The second factor in the hierarchical competitive activity structure of skilled female basketball players includes: in the 
won games "Offensive actions from long distances" - quantitative and qualitative indicators of 3-point shots, playing time, quantitative indicators of efficient assists and steals; in the lost games "Ball control" - offensive rebounds, defensive rebounds, total rebounds, fouls, and blocks.

The expert interpretation of the study results shows that in the won games the second factor "Offensive actions from long distances" includes the indicators of steals, which determine the effectiveness of fast and positional offensive actions, and, as a result, efficient assists. The high efficiency of quantitative and qualitative indicators of 3-point shots usually allows the winning team to maintain a comfortable advantage in the competitive activity. The indicator of playing time in the second factor shows that the winning team has skilled athletes, who are able to substitute other players in order to increase the competitive activity efficiency and actively counteract the opposing team's offensive actions during defense. In the lost games, the second factor includes the indicators of rebounds, blocks, and fouls. As we can see, the composition of the second factor in the lost games "Ball control" almost completely duplicates similar technical and tactical indicators, which belong to the first factor in the won games and determine the indicators of ball control. This creates the preconditions for increasing the effectiveness of offensive technical and tactical actions, their variability (fast or positional attacks), or their combinations. Exceptions are the indicators of fouls, which significantly reduce the indicators of ball control by the team in the competitive activity and, as a result, the overall effectiveness and efficiency of the competitive activity. In the competitive activity structure of skilled female basketball players, the second factor is $18.5 \%$ in the won games, $18.4 \%$ - in the lost games.

The third factor in the hierarchical competitive activity structure of skilled female basketball players includes: in the won games "Game and standard offensive actions" - quantitative and qualitative indicators of 2-point shots, free throws, points scored; in the lost games "Efficient assists" - quantitative indicators of efficient assists and steals.
The expert interpretation of the obtained data shows that the third factor of the hierarchical competitive activity structure in basketball in the won games "Game and standard offensive actions" includes: indicators of shooting skills with differentiation into variable (quantitative and qualitative indicators of 2-point shots) and standard components (quantitative and qualitative indicators of free throws). In addition, this factor includes the indicators of total points as a logical reflection of the effectiveness of shooting skills.

In the lost games, the third factor "Efficient assists" includes indicators that directly determine the indicators of ball control by the team (steals) and the efficiency of offensive technical and tactical actions (efficient assists). In the competitive activity structure in basketball (based on the material of skilled female athletes), the third factor is $21.4 \%$ in the won games, $11.4 \%$ - in the lost games. Significant differences in the obtained data resulted from the fact that the won games have the most frequently used technical and tactical indicators in the competitive activity of skilled female basketball players (quantitative and qualitative indicators of 2-point shots and free throws, quantitative indicators of points scored). In the lost games, the third factor includes only the indicators of steals and efficient assists.

The fourth factor in the hierarchical competitive activity structure of skilled female basketball players includes: in the won games "Turnovers" - fouls and turnovers; in the lost games "Game and standard offensive actions" - quantitative and qualitative indicators of 2-point shots and free throws.

The quantitative indicators of fouls and turnovers directly determine the reduced indicators of ball control by the team in the competitive activity in the won games. In the lost games, the fourth factor "Game and standard offensive actions" includes quantitative and qualitative indicators that characterize shooting skills in variable conditions of the competitive activity (2-point shots) and in standard conditions (free throws). In the competitive activity structure of skilled female basketball players, the total contribution of the fourth factor is $9.7 \%$ in the won games, $19.2 \%$ - in the lost games.

Table 4. Generalized data of the grouping of elements of the competitive activity structure of skilled female basketball players in accordance with the values of factor coefficients in the won and lost games, $n=52$

\begin{tabular}{|c|c|c|c|c|}
\hline \multirow[t]{2}{*}{ Competitive activity } & \multicolumn{4}{|c|}{ Factors } \\
\hline & "Ball control" & $\begin{array}{c}\text { "Offensive actions from } \\
\text { long distances" }\end{array}$ & $\begin{array}{c}\text { "Game and standard of- } \\
\text { fensive actions" }\end{array}$ & “Turnovers" \\
\hline \multirow[t]{6}{*}{ won games } & rebound-O** & time $^{*}$ & 2-point shots ${ }^{\star}$ & fouls* \\
\hline & rebound-D $\mathrm{D}^{\star *}$ & 3 -point shots ${ }^{* *}$ & $\%$ 2-point shots* & turnovers* \\
\hline & rebounds $^{* *}$ & $\%$ 3-point shots ${ }^{* *}$ & free throws & - \\
\hline & blocks & efficient assists ${ }^{*}$ & $\%$ free throws & - \\
\hline & - & steals & points & - \\
\hline & $\begin{array}{l}\text { "Offensive action, } \\
\text { from long distances" }\end{array}$ & s"Ball control” & "Efficient assists" & $\begin{array}{l}\text { "Game and standard offensive } \\
\text { actions" }\end{array}$ \\
\hline \multirow[t]{5}{*}{ lost games } & time $^{\star}$ & rebound-O ${ }^{* *}$ & efficient assists ${ }^{\star \star}$ & 2-point shots ${ }^{*}$ \\
\hline & 3-point shots ${ }^{* *}$ & rebound-D & steals $^{* *}$ & $\% 2$-point shots \\
\hline & $\%$ 3-point shots ${ }^{* *}$ & rebounds ${ }^{\star *}$ & - & free throws ${ }^{* *}$ \\
\hline & turnovers & fouls & - & $\%$ free throws ${ }^{* *}$ \\
\hline & points ${ }^{\star *}$ & blocks ${ }^{\star *}$ & - & - \\
\hline
\end{tabular}

* - with a factor coefficient from $>0.5$ to $<0.7$; * - with a factor coefficient $>0.7$; rebound-O - offensive rebounds; rebound-D - deffensive rebounds 
Table 4 shows the elements of the competitive activity structure of skilled female basketball players in accordance with the values of factor coefficients in the won and lost games.

\section{Discussion}

The present experimental study for the first time provided data on grouping technical and tactical indicators of the competitive activity of skilled female basketball players in the final tournament of the European Basketball Championship 2017, with differentiation into won and lost games. The study confirmed the experts' opinion (Doroshenko, Sushko, Koryahin, Pityn, Tkalich, \& Blavt, 2019; Teck, Wang, \& Mallett, 2012) on the possibility of studying technical and tactical indicators of the competitive activity of skilled female basketball players using principal component analysis in won and lost games, which makes it possible to develop prerequisites for improving the training and competitive process, supplementing the system of knowledge about the general theory of athlete training.

In the modern system of athletic training, principal component analysis does not belong to the group of the most popular multivariate mathematical and statistical methods used in physical education and sports, due to a fairly high complexity of methods for selecting indicators and interpreting the obtained results (Kozina, Bazylyuk, \& Boyko, 2017; Shepelenko, Kozina, Cieślicka, Prusik, Muszkieta, Sobko, Ryepko, Bazilyuk, Polishchuk, Osiptsov, \& Kostiukevych, 2017). The main purpose of using principal component analysis in the theory of athletic training is to reduce the number of competitive activity indicators based on their classification and determination of the structure of internal relationships. By identifying and grouping the hidden (latent) factors that explain the relationships between basketball players' technical and tactical indicators in the competitive activity, specialists have the opportunity to analyze data on the identified factors, which, to a large extent, determine factor loadings of the competitive activity indicators (at a level close to 70\%) (Doroshenko, Sushko, Koryahin, Pityn, Tkalich, \& Blavt, 2019; Teck, Wang, \& Mallett, 2012).

For the practice of athletic training and analysis of the competitive activity, relevant are the tasks of analyzing largescale data - indicators of technical and tactical actions of basketball players with different positions in the competitive activity (Sampaio, Janeira, Ibáñez, \& Lorenzo, 2006).

The application of principal component analysis, classification, and further interpretation of the competitive activity indicators of highly skilled female basketball players enables solutions of such tasks and serves to achieve two goals: first, to reduce technical and tactical indicators in the competitive activity of highly skilled female basketball players and to identify technical and tactical indicators with the largest "factor weight"; secondly, to classify technical and tactical indicators in basketball competitive activity on the basis of identification and grouping of factors (Kozina, Jagiello, \& Jagiello, 2015; Kyrychenko \& Doroshenko, 2006).

Additionally, researchers (Doroshenko, Sushko, Koryahin, Pityn, Tkalich, \& Blavt, 2019) point out that the use of principal component analysis for the competitive activity has significant similarity with factor analysis when formulating tasks and a number of fundamental differences:

- principal component analysis does not use iterative clustering methods to categorize the indicators of basketball competitive activity into groups of factors;
- differentiation of the competitive activity leading indicators, which are used to extract principal components, and auxiliary indicators of basketball competitive activity;

- projection of auxiliary indicators of basketball competitive activity onto the primary $\mathrm{R}$ matrix of factor space;

- $\quad$ use of principal component analysis to classify both leading and auxiliary indicators of the competitive activity, as well as to make observations (when differentiating into friendly, control, official games, etc.). Besides, the issues of selecting the competitive activity indicators and interpreting the obtained results using principal component analysis are debatable. The greatest difficulty in selecting technical and tactical indicators of the competitive activity structure of skilled female basketball players is the need to differentiate technical and tactical indicators, which, to some extent, duplicate factor loadings. In the case of basketball, we are talking about the technical and tactical indicators in the competitive activity structure, which are used to assess the effectiveness of integrated technical and tactical skills (Simović, Matković, Mijanović, Kocić, \& Vojvodić, 2012) - free throws, 2-point and 3-point shots. In the process of studying the competitive activity structure, these technical and tactical indicators, in some way, duplicate the corresponding factor values during multivariate mathematical analysis. However, these technical and tactical indicators have considerable differences, which is also of importance (Gryko, Mikołajec, Maszczyk, Cao, \& Adamczyk, 2017) for performing adequate procedures of multivariate mathematical analysis of the competitive activity using principal component analysis - these groups of shots are differentiated by the number of points scored. Researchers believe that it is possible to use different methodological approaches to solve this problem (Tyshchenko, Hnatchuk, Pasichnyk, Bubela, \& Semeryak, 2018). It is reasonable to apply duplicating technical and tactical indicators of the competitive activity structure in basketball (analysis of the indicators of free throws, 2 -point and 3-point shots) in the process of multivariate mathematical and statistical analysis by principal component analysis, as changes in the primary $\mathrm{R}$ matrix are not statistically significant and will not essentially affect the grouping of factors. Also justified is a methodological approach, in which technical and tactical indicators that duplicate factor loadings in the primary matrix - indicators of free throws, 2-point and 3-point shots are combined into a group of "shots" for further analysis and interpretation.

Among unsolved issues are also the problems of interpretation of technical and tactical indicators obtained as a result of using multivariate mathematical and statistical methods - applying principal component analysis with Kaiser normalization and varimax orthogonal rotation of the primary $\mathrm{R}$ matrix. In this case, the debatable issues include the problems of interpreting the "playing time" indicator, which can be used both as a value to calculate the individual (relative) effectiveness of the competitive activity of skilled female basketball players, and as a separate technical and tactical indicator, which integrally reflects the athlete's level of technical and tactical skills (Doroshenko, Sushko, Koryahin, Pityn, Tkalich, \& Blavt, 2019). We believe that these methodological approaches can be used in the procedures of multivariate mathematical and statistical analysis of the com- 

of the Competitive Activity Structure of Skilled Female Basketball Players

petitive activity structure of skilled female basketball players using principal component analysis, with the availability of qualified specialists' opinions in each individual case.

In addition to the above, in scientific discussion, of importance are the issues of developing an algorithm for multivariate mathematical and statistical analysis to study the competitive activity structure of skilled female basketball players using principal component analysis. This algorithm should contain the following elements: selection of technical and tactical indicators of the competitive activity structure in basketball; identification of principal components using Kaiser normalization and varimax orthogonal rotation of the primary R matrix; special analysis and interpretation of technical and tactical indicators of the competitive activity structure in basketball; development of methodological recommendations on improving the training and competitive activity. Despite the existence of controversial points, we believe that principal component analysis is adequate for studying the competitive activity structure of skilled female basketball players. The differentiation of technical and tactical indicators and their grouping in won and lost games will enable the development of necessary preconditions to increase the efficiency of the training and competitive activity.

The prospects for further research in this area are based on specifying and detailing the algorithm for analyzing the structure of the training and competitive activity of skilled female basketball players using principal component analysis.

\section{Conclusions}

The study of the competitive activity structure of skilled female basketball players by methods of multivariate mathematical and statistical analysis (principal component analysis) reveals considerable differences in won and lost games, with four most significant indicators of factor loadings and a sample of elements that correlate with one another, the percentage is $67.40 \%$ for won games and $69.52 \%$ - for lost games, which shows a high degree of reliability of the obtained experimental results (about $70 \%$ ). The differences in the hierarchical competitive activity structure of skilled female basketball players in won and lost games are recorded in four factors.

The methods of multivariate mathematical and statistical analysis (in particular, principal component analysis) are effective and informative for studying the hierarchical competitive activity structure of skilled female basketball players. The greatest difficulties in studying the competitive activity structure in basketball using principal component analysis are the selection of indicators that do not duplicate one another, expert interpretation of the obtained results, and algorithmization of special analysis of technical and tactical indicators.

\section{Acknowledgement}

The experimental study was conducted in accordance with the plans of research work of the Department of Physical Rehabilitation, Sports Medicine, Physical Education and Health, Zaporizhzhia State Medical University: "Optimization of Students' Physical State by Means of Physical Education and Sports in a Medical Higher Education Institution", state registration number 0117U006965; the Department of
Physical Education and Sports Pedagogy, Borys Grinchenko Kyiv University: "Theoretical and Practical Foundations of Using Fitness Technologies in Physical Education and Sports", state registration number 0118U001229; the Department of Theory and Methods of Sports Training, Prydniprovska State Academy of Physical Culture and Sports: "Historical and Methodological Foundations of Managerial Approaches to Athlete Training System", state registration number $0116 \mathrm{U} 003013$.

\section{Conflict of interest}

The authors declare no competing interest.

\section{References}

Bazanov, B., Võhandu, P., \& Haljand, R. (2006). Factors influencing the teamwork intensity in basketball. International Journal of Performance Analysis in Sport, 6(2), 88-96. https://doi.org/10.1080/24748668.2006.11868375

Calvo, J.L., García, A.M., \& Navandar, A. (2017). Analysis of mismatch after ball screens in Spanish professional basketball. International Journal of Performance Analysis in Sport, 17(4), 555-562. https://doi.org/10.1080/24748668.2017.1367999

Cieślicka, M., Sobko, I., Ulaeva, L., Ishenko, O., Shepelenko, T., Tamozhanska, G., \& Bugayets, N. (2019). Improving the protective technique of 13-14-year-old basketball players using rubber bands and unstable platforms. Journal of Physical Education and Sport, 19(3), 903-911. https://doi.org/10.7752/jpes.2019.s3130

Doroshenko, E., Sushko, R., Koryahin, V., Pityn, M., Tkalich, I., \& Blavt, O. (2019). The competitive activity structure of highly skilled basketball players on the basis of factor analysis methods. Human Movement, 20(4), 33-40. https://doi.org/10.5114/hm.2019.85091

Ferreira, A.P., Volossovitch, A., \& Sampaio, J. (2014). Towards the game critical moments in basketball: a grounded theory approach. International Journal of Performance Analysis in Sport, 14(2), 428-442. https://doi.org/10.1080/24748668.2014.11868732

Gryko, K., Mikołajec, K., Maszczyk, A., Cao, R., \& Adamczyk, J. (2017). Structural analysis of shooting performance in elite basketball players during FIBA EuroBasket 2015. International Journal of Performance Analysis in Sport, 18(2), 380-392. https://doi.org/10.1080/24748668.2018.1479923

Jiang, H. (2014). Research of Chinese men's basketball team development countermeasures based on the analytic hierarchy process. BioTechnology: An Indian Journal, 10(11), 4994-5003.

Kawabata, M., \& Mallett, C.J. (2012). Interpreting the Dispositional Flow Scale-2 scores: A pilot study of latent class factor analysis. Journal of Sports Sciences, 30(11), 1183-1188. https://doi.org/10.1080/02640414.2012.695083

Kozina, Z., Repko, O., Ionova, O., Boychuk, Y., \& Korobeinikov, V. (2016). Mathematical basis for the integral development of strength, speed and endurance in sports with complex manifestation of physical qualities. Journal of Physical Education and Sport, 16(1), 70-76. https://doi.org/10.7752/jpes.2016.01012

Kozina, Z., Jagiello, W., \& Jagiello, M. (2015). Determination of sportsmen's individual characteristics with the help of mathematical simulation and methods of multi- 
dimensional analysis. Pedagogics, Psychology, MedicalBiological Problems of Physical Training and Sports, 19(12), 41-50. https://doi.org/10.15561/18189172.2015.1207

Kozina, Z.L., Bazylyuk, T.A., \& Boyko, A.G. (2017). Analysis of the structure of the integrated preparedness of qualified handballers using multidimensional analysis methods. Health, sport, rehabilitation, 3(2), 15-24.

Koryahin, V., Dutchak, M., Iedynak, G., Blavt, O., Galamandjuk, L., \& Cherepovska, E. (2018). The technical and physical preparation of basketball players. Human Movement, 19(4), 29-34. https://doi.org/10.5114/hm.2018.77321

Križan, M., \& Mikulič, M. (2018). Dependence of the Result on the Effectiveness of Performance in the World Women's Handball Championship 2016. Theory and Methods of the Physical Education 18(2), 63-68. https://doi.org/10.17309/tmfv.2018.2.02

Kyrychenko, R., \& Doroshenko, E. (2006). Stady of the structure of technical and tactical activities of qualified basketball players by the method of main components. Pedagogics, psychology, medical-biological problems of physical training and sports, (5), 36-41.

Li, Y., Wang, X., Chen, X., \& Dai, B. (2015). Exploratory factor analysis of the functional movement screen in elite athletes. Journal of Sports Sciences, 33(11), 1166-1172. https://doi.org/10.1080/02640414.2014.986505

Liju, G. (2013). Statistical Analysis of Technical Characteristics of Eastern and Western Players in 2013 NBA All-star Game Based on MATLAB. Information Technology Journal, 12(16), 3612-3618. https://doi.org/10.3923/itj.2013.3612.3618

Makuts, T.B., \& Vysochina, N.L. (2015). Factorial analysis of tennis players' psychological and technical-tactic fitness at the stage of specialized basic training. Pedagogics, psychology, medical-biological problems of physical training and sports, 19(9), 45-50.

https://doi.org/10.15561/18189172.2015.0907

Pluta, B., \& Andrzejewski, M. (2018). Analysis of team sports results based on the European basketball men's championships. Trends in Sport Sciences, 1(25), 21-27. https://doi.org/10.23829/TSS.2018.25.1-3

Okazaki, V.H.A., Rodacki, A.L.F., \& Satern, M.N. (2015). A review on the basketball jump shot. Sports Biomechanics, 14(2), 190-205. https://doi.org/10.1080/14763141.2015.1052541

Sampaio, J., Janeira, M., Ibáñez, S., \& Lorenzo, A. (2006). Discriminant analysis of game-related statistics between basketball guards, forwards and centres in three professional leagues. European Journal of Sport Science, 6(3), 173-178. https://doi.org/10.1080/17461390600676200
Scanlan, A., Dascombe, B., \& Reaburn, P. (2011). A comparison of the activity demands of elite and sub-elite Australian men's basketball competition. Journal of Sports Sciences, 29(11), 1153-1160. https://doi.org/10.1080/02640414.2011.582509

Shepelenko, T., Kozina, Z., Cieślicka, M., Prusik, K., Muszkieta, R., Sobko, I., Ryepko, O., Bazilyuk, T., Polishchuk, S., Osiptsov, A., \& Kostiukevych, V. (2017). Factor structure of aerobics athletes preparation. Pedagogics, psychology, medical-biological problems of physical training and sports, 21(6), 345-352. https://doi.org/10.15561/18189172.2017.0606

Simović S., Matković B., Mijanović M., Kocić M., \& Vojvodić, M. (2012). Structure of efficiency factor at XIII, XIV, XV, and XVI World Championship in basketball. Journal of Human Sport and Exercise, 7(2), 527-543. https://doi.org/10.4100/jhse.2012.72.16

Sporiš, G., Šango, J., Vučetić, V., \& Mašina, T. (2006). The latent structure of standard game efficiency indicators in basketball. International Journal of Performance Analysis in Sport, 6(1), 120-129.

https://doi.org/10.1080/24748668.2006.11868360

Sushko, R., Vysochina, N., Vorobiova, A., Doroshenko, E., Pastuhova, V., \& Vysochin, F. (2019). Psychological selection in game sports on the basketball example. Journal of Physical Education and Sport, 19(3), Art. 250, 1708-1714. https://doi.org/10.7752/jpes.2019.03250

Tao Zhang, Gongzhu Hu, \& Qi Liao (2013). Analysis of offense tactics of basketball games using link prediction. 2013 IEEE/ACIS 12th International Conference on Computer and Information Science (ICIS). https://doi.org/10.1109/ICIS.2013.6607842

Teck, K.K., Wang, C.K.J., \& Mallett, C.J. (2012). Discriminating Factors between Successful and Unsuccessful Elite Youth Olympic Female Basketball Teams. International Journal of Performance Analysis in Sport, 12(1), 119-131. https://doi.org/10.1080/24748668.2012.11868588

Tyshchenko, V., Hnatchuk, Y., Pasichnyk, V., Bubela, O., \& Semeryak, Z. (2018). Factor analysis of indicators of physical and functional preparation for basketball players. Journal of Physical Education and Sport, 18(4), 1839-1844. https://doi.org/10.7752/jpes.2018.s4269

Villa, G., \& Lozano, S. (2018). Dynamic Network DEA approach to basketball games efficiency. Journal of the Operational Research Society, 69(11), 1738-1750. https://doi.org/10.1080/01605682.2017.1409158

Wei Yin (2014). Principal component factor analysis-based NBA player comprehensive ability evaluation research. Journal of Chemical and Pharmaceutical Research, 6(6), 2400-2405. 


\title{
АНАЛІЗ СТРУКТУРИ ЗМАГАЛЬНОГО ПРОЦЕСУ КВАЛІФІКОВАНИХ БАСКЕТБОЛІСТОК
}

\author{
Едуард Дорошенко ${ }^{1 \mathrm{ABCD}}$, Руслана Сушко ${ }^{2 \mathrm{ABCD}}$, Валерій \\ Шамардін ${ }^{3 \mathrm{CDE}}$, Володимир Приходько ${ }^{4 \mathrm{CDE}}$, Ірина Шаповалова $^{1 \mathrm{DE}}$, \\ Дар'я Єлісєєва ${ }^{4 \mathrm{DE}}$, Оксана Демідова ${ }^{4 \mathrm{DE}}$, Артем Яковенко ${ }^{4 \mathrm{DE}}$ \\ Запорізький державний медичний університет \\ ${ }^{2}$ Київський університет імені Бориса Грінченка \\ ${ }^{3}$ Центр ліцензування Української футбольної асоціації \\ ${ }^{4}$ Придніпровська державна академія фізичної культури і спорту
}
Авторський вклад: А - дизайн дослідження; В - збір даних; C - статаналіз; D - підготовка рукопису; Е - збір коштів
Реферат. Стаття: 9 с., 4 табл., 33 джерел.

Мета дослідження - вивчити, проаналізувати і узагальнити структуру змагального процесу на підставі визначення ієрархії техніко-тактичних показників кваліфікованих баскетболісток у виграних і програних матчах 3 використанням методу головних компонент.

Матеріали та методи. Контингент - 96 професійних баскетболісток, гравців національних збірних команд Icпанії, Франції, Бельгії, Греції, Туреччини, Латвії, Італії та Словаччини, які зайняли 1-8 місця в фінальному турнірі чемпіонату Європи з баскетболу 2017 року. Проаналізовано 16 основних техніко-тактичних показників кваліфікованих баскетболісток у 52 офіційних іграх. Використаний метод головних компонент. Загальна кількість спостережень - 52.

Результати. Експериментальні показники, які отримані в ході дослідження, дозволили вивчити і проаналізувати групування елементів структури змагального процесу кваліфікованих баскетболісток, інтерпретувати отримані результати з метою визначення інформативних критеріїв для оптимізації тренувального діяльності та підвищення ефективності змагального процесу. Виявлено значущі відмінності структури змагального процесу у виграних і програних матчах: відповідно до найбільш значущих показників факторних навантажень, відсоток вибірки елементів, які корелюють між собою, становить: для виграних матчів - 67,40 \%, для програних матчів - 69,52\%.

Висновки. Метод головних компонент є ефективним та інформативним для вивчення структури змагального процесу кваліфікованих баскетболісток. Показано, що найбільшу складність в процесі вивчення структури змагального процесу в баскетболі методом головних компонент представляють відбір показників, що не дублюють один одного і не $є$ розрахунковими, експертна інтерпретація отриманих результатів та алгоритмізація спеціального аналізу техніко-тактичних показників.

Ключові слова: баскетбол, структура, техніко-тактична активність, аналіз головних компонент.

\section{Information about the authors:}

Doroshenko Eduard: doroe@ukr.net; https://orcid.org/0000-0001-7624-531X; Department of Physical Rehabilitation, Sports Medicine, Physical Education and Health, Zaporizhzhia State Medical University, Mayakovsky, St, 26, Zaporizhzhia, 69035, Ukraine. Sushko Ruslana: r.sushko@kubg.edu.ua; https://orcid.org/0000-0003-3256-4444; The Faculty of Health, Physical Training and Sports, Borys Grinchenko Kyiv University, Marshala Tymoshenko St, 13-B, Kyiv, 04212, Ukraine.

Shamardin Valerij: clffu2017@gmail.com; https://orcid.org/0000-0003-4615-4972; Ukrainian Football Association Licensing Center, Laboratorniy by-St, 7-a, Kyiv, 01133, Ukraine.

Prykhodko Volodymyr: ops_infiz@ukr.net; https://orcid.org/0000-0001-6980-1402; Department of Theory and Methods of Sports Training, Prydniprovska State Academy of Physical Culture and Sports, Naberezhna Peremogy St, 10, Dnipro, 49094, Ukraine. Shapovalova Iryna: ivshapovalova@ukr.net; https://orcid.org/0000-0001-9911-9017; Department of Physical Rehabilitation, Sports Medicine, Physical Education and Health, Zaporizhzhia State Medical University, Mayakovsky, St, 26, Zaporizhzhia, 69035, Ukraine. Yelisieieva Daria: yelisieieva.daria@gmail.com; https://orcid.org/0000-0002-6763-3692; Department of Theory and Methods of Physical Education, Prydniprovska State Academy of Physical Culture and Sports, Naberezhna Peremogy St, 10, Dnipro, 49094, Ukraine.

Demidova Oksana: demidova@gmail.com; https://orcid.org/0000-0002-8524-5095; Department of Theory and Methods of Physical Education, Prydniprovska State Academy of Physical Culture and Sports, Naberezhna Peremogy St, 10, Dnipro, 49094, Ukraine. Yakovenko Artem: yakovenkoartem2012@gmail.com; https://orcid.org/0000-0003-0338-8437; Department of Sports Games, Prydniprovska State Academy of Physical Culture and Sports, Naberezhna Peremogy St, 10, Dnipro, 49094, Ukraine.

Cite this article as: Doroshenko, E., Sushko, R., Shamardin, V., Prykhodko, V., Shapovalova, I., Yelisieieva, D., Demidova, O., \& Yakovenko, A. (2020). Analysis of the Competitive Activity Structure of Skilled Female Basketball Players. Teoriâ ta Metodika Fizičnogo Vihovannâ, 20(4), 219-227. https://doi.org/10.17309/tmfv.2020.4.04

Received: 10.09.2020. Accepted: 20.12.2020. Published: 25.12.2020

This work is licensed under a Creative Commons Attribution 4.0 International License (http://creativecommons.org/licenses/by/4.0). 